\title{
The Influence of Smart Board Game Toward 4-5 years old Children's Cognitive Development
}

\author{
Kristin Anggraini, Siti Masitoh, Umi Anugerah Izzati \\ Universitas Negeri Surabaya \\ Surabaya, Indonesia \\ Kristinanggraini16070855014@mhs.unesa.ac.id
}

\begin{abstract}
The aim of this research is to develop children's cognitive through a game. This research adopts the quantitative research methodology with Experimental Design research design. The output of this research is to perform the influence of Smart Board Game toward children's Cognitive Development, whereas this issue is proven by the significant differences between the pretest and post-test result on 4-5 years old children's cognitive capability particularly in recognizing number and color. When playing the game, children are able to obtain experience, fun, and also knowledge. On the other side, Smart Board Game which is possibly include children's cognitive knowledge also could function to develop his or her cognitive aspect. In conclusion, this Smart Board Game is able to promote children's cognitive development, particularly in case of recognizing number and color.
\end{abstract}

Keyword - Cognitive Development; Smart Board Game; The children with age of 4-5 years old.

\section{INTRODUCTION}

Cognitive development is closely related to thinking capability. At the early age, children's cognitive development grows rapidly. According to [1] this cognitive development aspect is related with children's thinking process, especially in case of perception, memory, mind, symbol, reasoning, and also problem-solving. What a pity if the childhood moment, which will never be repeated again, is not fulfilled with activities which are able to evolve their development.

The constitution [2] on Clause 1 Point 14 mentioned that the significant education addressed for the early age children is to provide a readiness for them in facing the following education. The constitution also mentions the range of early age children since they were born up to 6 years old; whereas, in this particular age, all of the development aspects of the children will be evolved very rapidly.

During the first five years of a children living moment, the cognitive development aspect will be one of many development aspects that evolved rapidly. According to Piaget opinion [3], the children in between 2 up to 7 years old is categorized in pre-operational thinking level, where the children is thinking concretely, not logically, and also inconsistently at this level.

Based on the above explanation, it will be a necessity for the arrangement and guidance so that the children are able to develop based on their development level on the preoperational moment. This statement is suitable with the opinion of [4] that the lecturer can develop the cognitive development aspect of a children through a game which is suited with their development level. [5] stated the same opinion that playing game is an important part of a children's life because children will get experience and knowledge that can enhance their development aspects. The children always like to play whatever they want to do, it can be used to give educators a game that can stimulate the children's development aspects. [6] stated that children can learn while playing (learning by playing).

To design fun activities, the lecturer should become facilitators in pouring their creative ideas. Further creative ideas are used to design a media that can stimulate children's cognitive development so that their development will be more optimal. According to [7] the benefits of using instruction media, children will get more exciting, and meaningful experience. Thus, the media that be used to develop children's cognitive development, could be an attractive game.

A game which can be used to enhance children's cognitive development is the smart board game. Whereas this Smart Board Game is inspired by Galton marble board or frequently known as Galton's Board, which is one of the discovery found by Sir Francis Galton in 1878, and this Smart Board game also designed based on the children's development level.

This Smart Board game consists of a piece of rectangle wooden board with the size of $100 \mathrm{~cm} \mathrm{X} 58 \mathrm{~cm}$. This board is intentionally made sideling with $50 \mathrm{~cm}$ height, painted colorfully with lines for tracks and numbers. As for the sideling has $50 \mathrm{~cm}$ height suited with children's high waist, so that children can play it while standing. Moreover, Smart Board game is also completed with wedges stuck on the board and decorated with beads and colorful ping pong balls which are given a number on it. The colorful display of Smart Board game draw children's attention. All children show improvement of arithmetic in his cognitive development easily and relatively quick through its participation in the game [8] In this study, researchers want to emphasize on children's cognitive development aspects on the concept of mentioning the number, knowing the number, matching the appropriate color, and also counting many objects. Thus, when children play the Smart Board game, they will feel more attracted and happier, but without feeling depressed because it's all about a game. When they play in a fun atmosphere they will easily accept new knowledge. It can help the children to send such 
information from short-term memory to long-term memory, so that the knowledge has been obtained may be long remembered by them. Thus, by using this game the learning activity become more applicative, contextual and fun.

According to Cosby and Sawyer [7] the game can develop all children's development aspects through individual training, and also as a group. Smart Board Games also teach them to learn to resolve conflicts with other people or the environment.

According to [9] by leading the children to play game board with a number on it can enhance cognitive development. Even [9] suggest to use numbering game board to increase the children's cognitive development, whereas this game is easily produced, useful, and it need only a short time for playing and also inexpensive.

Thus, the numbering game board such as Smart Board game is estimated can promote cognitive development based on the children's development level.

Based on this argument, the researcher wants to carry out a research about the influence of Smart Board game toward the cognitive development of 4-5 years old children. This research also tries to answer the existing problem that is "Is there an influence of Smart Board game toward cognitive development toward 4-5 years old children?

\section{METHOD}

This research uses quantitative research approach. The research design which used is Experimental Design. The research subject consists of 30 children that takes place at Kindergarten located at Sidoarjo.

The research instrument consists of the children's cognitive development observation sheet, such as mentioning the number, knowing the number, matching the appropriate color, and also counting many objects. The instrument reliability test uses the formula of Cronbach's Alpha, which is assisted the program of SPSS 22 for windows evaluation version. If the alpha points are more than 0.60 so that the data is considered good enough and reliable. The homogeneity and normality test are used to find out whether the data is homogenous and distributed normally. The hypothesis test is due to find out the influence of Smart Board game after being implemented in the class which is referred to different point output of pre-test and post-test. The hypothesis test in this research is carried out by significance standard of 0.05 .

\section{The rules of the Smart Board games}

The children run from his seat to the colorful ping pong balls. They take one colored ping pong balls, then mention the numbers stamped on the ball. They jump with the use of one leg (left leg) while enumerating the figures indicated in the appropriate spheres toward the Smart Board.

Children stand at the top of the Board while pairing the numbers stamped on the ball with the number that appears on the path. They roll a ball on the right path. They jump with the use of one leg (right leg) while enumerating appropriate numbers stamped on the ball, from the top of the Smart Board toward the bottom of the Board, then pick up a ball that has rolled and got to the bottom of the path Board.

Children do a frog leap to beads collection by bringing ping pong balls. They take beads according to ping pong ball's color than counting the number printed on the ping-pong balls on their hand. Then, they ran from where the beads to sit again.

\section{RESULTS AND DISCUSSION}

The number of research subject is 30 children, which is consist of 18 girls and 12 boys. The data in this research is analyzed by using linear regression and descriptive analysis.

\section{The validity test of cognitive capability}

The validity test of cognitive capability in this research was using the construct validity, it is observation sheet of the children's cognitive development capability for each item of the indicator. Every item of statement or validation indicator is consulted with the experts. Then this instrument is trialed and analyzed by using the formula of Pearson Correlation Sig (2tailed) with the assistance of SPSS 22.0 for windows evaluation version. The analysis result of the children's cognitive development capability validity test is shown as follows:

\section{TABLE 3.1 The Validity Test of Cognitive}

Development Capability

\begin{tabular}{|c|c|c|}
\hline Instrument & $\begin{array}{c}\text { Pearson } \\
\text { Correlation }\end{array}$ & Note \\
\hline Cognitive 1 & 0.709 & valid \\
\hline Cognitive 2 & 0.825 & valid \\
\hline Cognitive 3 & 0.642 & valid \\
\hline Cognitive 4 & 0.756 & valid \\
\hline
\end{tabular}

Based on the calculation of SPSS 22.0 for windows evaluation version on list 3.1 can be concluded that the validity tests the cognitive capability variable item can be seen from the coefficient point of r-count from each item which will be compared with r-list from the significant standard of 0.05 , where the point of r-list is 0.3610 . Based on the Pearson correlation, there will be a point for cognitive 1 item 0.709 , cognitive 2 item 0.825 , cognitive 3 item 0.642 , and cognitive 4 item 0.756. All of this point is higher than r-list 0.3610 , so this can be concluded that the research variable instrument for cognitive development capability is valid.

\section{The Reliability Test of Cognitive Capability}

The reliability test of cognitive development capability is based on the formula of Alpha Cronbach (a) with the support of SPSS 22.0 for windows evaluation version. The following is the estimation output of a reliability test of cognitive development capability: 
TABLE 3.2 The Reliability Test Cognitive Capability

\begin{tabular}{|c|c|}
\hline Cronbach's Alpha & N \\
\hline $\mathbf{0 . 8 6 4}$ & $\mathbf{4}$ \\
\hline
\end{tabular}

TABLE 3.3 Tests of Normality

\begin{tabular}{|c|c|c|c|c|c|c|}
\hline & \multicolumn{3}{|c}{$\begin{array}{c}\text { Kolmogorov- } \\
\text { Smirnov }\end{array}$} & \multicolumn{4}{c|}{ Shapiro-Wilk } \\
\cline { 2 - 7 } & $\begin{array}{c}\text { Statisti } \\
\boldsymbol{c}\end{array}$ & $\boldsymbol{d} \boldsymbol{f}$ & \multicolumn{1}{|c|}{ Sig. } & $\begin{array}{c}\text { Statisti } \\
\boldsymbol{c}\end{array}$ & $\boldsymbol{d} \boldsymbol{f}$ & Sig. \\
\hline $\begin{array}{c}\text { Pretest } \\
\text { cognitive }\end{array}$ & .139 & 30 & .141 & .933 & 30 & .058 \\
\hline $\begin{array}{c}\text { Posttest. } \\
\text { cognitive }\end{array}$ & .176 & 30 & .019 & .892 & 30 & .005 \\
\hline
\end{tabular}

a. Lilliefors Significance Correction

\section{The Normality Test of Cognitive Capability}

Based on the normality testing output by using Kolmogorov-Smirnov and Shapiro-Wilk in the above list can be found that the data of cognitive development post-test is increased than the pre-test data. The significance point or $\mathrm{p}$ value on the data of post-test according to KolmogorovSmirnov is $0.019<0.05$. And according to Shapiro-Wilk it is $0.005<0.05$, so that the data of the children cognitive development is not distributed normally. The assumption of normally is not fulfilled so that the Average Differences test of Paired Sample T-test is changed with the Differences Test by Wilcoxon.

Test Statistics

\begin{tabular}{|c|r|}
\hline & $\begin{array}{c}\text { Posttest Cognitive - } \\
\text { Pretest Cognitive }\end{array}$ \\
\hline Z & $-4.796^{\mathrm{b}}$ \\
\hline Asymp. Sig. (2-tailed) & .000 \\
\hline
\end{tabular}

a. Wilcoxon Signed Ranks Test

b. Based on negative ranks.

\section{TABLE 3.4. Test Statistics Pretest-Posttest Wilcoxon}

Based on the testing result of Wilcoxon, we can find out that the signs point or $\mathrm{p}$-value is $0.000<0.05$, so it is can conclude that there is a significant average difference between pre-test and post-test on the children's cognitive development.

Based on statistic calculation on the above list, it is known that the pre-test result of cognitive development on 30 children has a minimum point of 5.00 , maximum point 12.00 , mean point 8.5 , and standard deviation 2.19325 . Whereas the posttest result of cognitive development on 30 children has a minimum point of 11 , maximum point 16 , mean point 14.43 , and standard deviation of 1.35655. And from the average point, we can find out that the average point of post-test is higher than the pre-test, which this difference is significant according to a statistical test.

[10]This research shows that Smart Board game has a strong influence on the children's cognitive development capability, particularly at recognizing number $1-10$, counting number 1-10, and also recognizing colors. The children capability for cognitive development is expanded through a game, where at the time they play this Smart Board game, they also get a new education on the other side.

\section{TABLE 3.5 Descriptive Statistics}

\begin{tabular}{|c|c|c|c|c|c|}
\hline & $\mathrm{N}$ & $\begin{array}{c}\text { Minim } \\
\text { um }\end{array}$ & $\begin{array}{c}\text { Maxim } \\
\text { um }\end{array}$ & Mean & $\begin{array}{c}\text { Std. } \\
\text { Deviation }\end{array}$ \\
\hline $\begin{array}{c}\text { Pretest. } \\
\text { Cognitive }\end{array}$ & 30 & 5.00 & 12.00 & 8.5000 & 2.19325 \\
\hline $\begin{array}{c}\text { Posttest } \\
\text { Cognitive }\end{array}$ & 30 & 11.00 & 16.00 & 14.4333 & 1.35655 \\
\hline $\begin{array}{c}\text { Valid N } \\
\text { (listwise) }\end{array}$ & 30 & & & & \\
\hline
\end{tabular}

When children play in a fun atmosphere they can easily accept new knowledge. This can help them send such information from short-term memory to long-term memory, so that the knowledge has been obtained may be long remembered. They also able to interact with its environment through play, so thus all aspects of any development join the thrive [6]. It can affect children's development in the future. Every child can show an enhancement of the ability of their cognitive development easier and faster through their participation in playing Smart Board game [2].

The children experience during playing Smart Board game by mentioning, matching, and also counting number $1-10$ is proven can improve their cognitive development particularly in mathematics capability [3]. Children that play this game can absorb a variety of things or they will have better skills in problems solving compared with children who never play.

Based on the results of the research that has been done on the Smart Board game toward the influence of cognitive development, then the researchers give suggestions as follows: The Smart Board game can be used as an activity on the children's cognitive development capability, because Smart Board games are more interesting understanding the color, number and symbol.

\section{CONCLUSION}

This research offers a support for our hypothesis that the children who play Smart Board game will get a benefit in learning recognizing number and color. This finding provides a specific proof significantly from Smart Board game. All the children show an improvement of recognizing number and color after being participated in this game. At the earlier observation, it is found that children's cognitive capability in recognizing number and color is relatively low, it is caused by lack of stimulation on them. Thus, the researcher who is interested in exploring the children's cognitive capability also should consider the differences in their experience.

\section{REFERENCES}

[1] A. Susanto, Perkembangan anak usia dini: Pengantar dari berbagai 
aspeknya. Kencana, 2011.

[2] P. R. Indonesia, "Undang-undang Republik Indonesia nomor 20 tahun 2003 tentang sistem pendidikan nasional," Jakarta Pemerintah Republik Indones., 2003.

[3] J. Hurlock and M. L. Wilson, "Searching Twitter: Separating the Tweet from the Chaff.," in Icwsm, 2011, pp. 161-168.

[4] E. Oppermann, Y. Anders, and A. Hachfeld, "The influence of preschool teachers' content knowledge and mathematical ability beliefs on their sensitivity to mathematics in childrenren's play.," Teach. Teach. Educ., vol. 58, pp. 174-184, 2016.

[5] S. Dockett and M. Fleer, Play and pedagogy in early childrenhood: Bending the rules. Harcourt Brace, 1999.

[6] Y. N. Sujiono, "Konsep dasar pendidikan anak usia dini,” 2009.
[7] A. Sudono, Sumber belajar dan alat permainan untuk pendidikan anak usia dini. Grasindo, 2000.

[8] O. Cankaya, J.-A. LeFevre, and K. Dunbar, "The role of number naming systems and numeracy experiences in childrenren's rote counting: Evidence from Turkish and Canadian childrenren," Learn. Individ. Differ., vol. 32, pp. 238-245, 2014.

[9] G. B. Ramani and R. S. Siegler, "Promoting broad and stable improvements in low-income childrenren's numerical knowledge through playing number board games," Children Dev., vol. 79, no. 2, pp. 375 394, 2008.

[10]F. M. M. Lucas, "The Game as an Early Childrenhood Learning Resource for Intercultural Education,” Procedia-Social Behav. Sci., vol. 237, pp. 908-913, 2017. 